\title{
Urban Population and Economic Growth: South Asia Perspective
}

\author{
Sandip Sarker \\ Arifuzzaman Khan \\ Mehdad Mamur Mannan
}

\begin{abstract}
Previously economic growth was generally discussed in terms of foreign direct investment (FDI), educational growth, savings, investments, inflation as well as trade openness of a nation. Very recently it has been identified that population is one of the major determinants of economic growth of a nation. In the recent years, the study of urbanization has gained a matter of concern in developing countries as it has been recognized as part of a larger process of economic development which is affecting developing countries. South Asian countries are one of the emerging economics and growing at a faster rate over the past few years. At the same time, population of South Asia is growing at a significant rate. Therefore the study has attempted to identify the causal relationship between urban population and economic growth in South Asia using a panel data analysis. The study makes use of the Augmented Dickey-Fuller (ADF) and Phillips-Perron (PP), Pesaran as well as Fisher methods for panel unit root test. The panel Pedroni cointegration test suggests that there is long run relationship between the variables. The further panel Vector Error Correction Model (VECM) suggests that there is long run causality running from urban population growth to economic growth in South Asia. The study concludes that the growth of urban population can have significant impact on economic growth in South Asia in the long run.
\end{abstract}

\section{Keywords}

Urban Population; Economic Growth; South Asia; Vector Error Correction Model; Panel Data.

\section{JEL Classification}

O18; C32; J10; R11. 


\section{Introduction}

Urbanization can be defined as 'the demographic process whereby an increasing share of the national population lives within urban settlements.' Urbanization is closely linked to economic development of a society. As an economy develops, relative and absolute changes in demand increase the relative and absolute importance of the manufacturing and service sectors. According to United Nations projections, 54 per cent of the world's population used to reside in urban areas in 2014. Many economists welcomed this continued increase in the share of the population living in urban areas in recent decades as they believe urbanization is a positive achievement on the track toward wealth and prosperity. According to this view, urbanization reinforces and improves economic growth and therefore increases the wealth of nations in the long run.

According to the urban economists, urbanization is a complex phenomenon. They have also identified some positive effects of urbanization. At first small cities can rapidly develop and new economic and political structures emerge. Successful segments within the city attract additional investment, generate increased demand for labour force and elicit migration to the city as a further instrument of urban growth. As the quality of life increases, those cities may become a major attractor for poor rural populations, which will lead to creation of large urban unemployment. The evidence of a positive link between cities (urban areas) and economic development is prodigious. Friedberg and $\mathrm{Hu}$

nt (1995) mentioned that population growth and urbanization go together, and economic development is closely related with urbanization. Additionally, Bloom, Canning and Fink (2008), found that there is no evidence that urbanization level affects economic growth rate. This research has highlighted the importance of reassessing the relationship between urbanization and economic growth, and makes us rethink profoundly the popular ideas and practice of accelerated urbanization in developing countries. Very recently, Turok and McGranahan (2013) have also argued that it is not urbanization or the city size per se that induces economic growth; rather it is infrastructure and institutional settings of the country.

The population of South Asia is projected to cross 2 billion at the end of 2020 . The world population by 2050 will see 2.3 billion additional people are being added to the world population. No doubt, population is going to be a major challenge for developing countries, especially for countries in South Asia. At the same time there has been a tendency of people moving towards urban areas for better opportunities. There are people who are engaged in different economic activities and contributing to our economic development as well. Given its impact on the majority of the world's population and the sustainable development of the global economy, the relationship between urbanization and economic growth is of remarkable scientific and societal importance. Therefore our study aims to identify the relationship between urban population and economic growth of south Asia from a panel data analysis. The findings can provide important policy suggestion regarding the expected economic benefit obtaining from rapid urbanization and achieve sustainable development.

We consider our paper to a complement of the existing line of research that relies heavily on the long run relationship. The rest of the paper has been organized as follows. Section 2 summarizes the literatures on relationship between urban population growth and economic growth of the developed and developing economies. Section 3 describes the data and methodology of the study. Section 4 discusses the econometric procedures and empirical results. Section 5 concludes the give policy recommendations. 


\section{Literature Review}

There are varieties of ways through which urbanization can affect economic growth of a country and the majority of studies suggest that urbanization should have a positive impact on economic growth of a nation. Mills and Becker (1986) found a positive relationship between the urban population growth and GNP per capita and a negative one between per cent urban and the agricultural share. Kasman and Duman (2015) found a short-run unidirectional panel causality running from urbanization to gross domestic product (GDP). However, the impact of urbanization on economic growth is diverse across countries based on their level of annual income and development. Moomaw and Shatter (1993) applied different measures of urbanization and urban concentration on growth and find that metropolitan concentration has a positive impact while urban primacy, defined as concentration of urban population in the largest city, has a negative impact. Rosenthal and Strange (2003) argued that doubling the size of cities can lead to an increase in productivity in between 3 to 8 per cent that is urban areas generate 85 per cent of GDP in high-income countries. At the same time Glaeser, Rosenthal and Strange (2010) stressed the role of urbanization to promote entrepreneurship. According to them urban populations access to finance helps to promote their ideas and to some extent enable them to do business in their own locality. Bacolod, Blum and Strange (2010) examined the effect of urbanization of economic growth of a nation. They believe that urban concentration causes interactions and engenders spillovers of knowledge and skills which enable people to upgrade their skills and knowledge more efficiently. This raises productivity in urban areas which ultimately affects economic growth of a nation. In the study of Quigley (2007) it is evident that Mexico City accounts for 20.8 per cent of Mexico's total population and 34.3 per cent of GDP, which indicates urbanization contributes significantly to the national GDP. Chen et al. (2014) in their work on global pattern of urbanization and economic growth from the last three decades found close links between urbanization levels and GDP per capita. However they found no correlation between urbanization speed and economic growth rate at the global level.

However some studies also found negative relationships between urbanization and economic growth. Alam et al. (2007) argued that rapid urbanization can negatively impact the economy via its effect on damaging infrastructures. Shabu (2010) in her study on urbanization and economic development in developing countries found that there is weak relationship between urban growth and economic development in developing countries. However in the case of developed countries, urbanization has a positive impact on economic growth. Castells (2011) believes that the consequence of urbanization on economic growth is a complex phenomenon and depends on several factors such as level of development, stage of urbanization, and nature of main economic activities.

There are several studies that focus on population changes and its impact on economic growth. However only a few of those focused on urban population and its economic impact. Our study is contributed to the existing literature on population and growth by adding an outcome from a cross-country analysis using panel data in South Asia.

\section{Urbanization and Growth in South Asia}

According to the World Bank statistics $561,129,658$ people lived in urban areas in South Asia in 2014. At the same time total GDP is estimated nearly $\$ 1,938$ billion in South Asia in 2014. However this region seems to fail in utilizing its huge urban population. South Asia is made up of Afghanistan, Bangladesh, Bhutan, Nepal, India, Maldives, Pakistan and Sri Lanka which produced just 9 per cent of global GDP in 2013, despite having roughly 14 per cent of the world's urban population. By contrast, East Asia includes China, Hong Kong, Japan, Mongolia, North and South Korea and Taiwan fared much better, producing 29 per cent of GDP, and 
with 32 per cent of the urban population, in the same period. As the population of South Asia is expected to grow by 250 million over the next 15 years, the region could be left further behind if it is unable to harness the benefits of urbanization. Between 2000 and 2012, average real GDP per capita increased by almost 56 per cent, from $\$ 2,556$ to $\$ 3,999$, with annual GDP per capita growth rates of more than 4.5 percent a year in all countries except Nepal and Pakistan. And while half of South Asians were living on less than $\$ 1.25$ a day in 1999 , fewer than a third were doing so by 2010 (World Urbanization Prospects Database, 2011). Since 2000, the report found, South Asia has made good strides in achieving greater prosperity with the increase in productivity linked with the growing number of people living in the region's towns and cities. Still, South Asia's share of the global economy remains extremely low relative to its share of the world's urban population, and, in general, urbanization in the region remains underleveraged. The share of the region's population officially classified as living in urban settlements increased only marginally from 27.4 per cent in 2000 to 30.9 per cent in 2011, an annual growth rate of 1.1 per cent. According to Peter Ellis, a lead urban economist with the World Bank's Social, Urban, Rural and Resilience Global Practice, a big reason why South Asia is not fully realizing the potential of its cities for prosperity and livability is that its urbanization has been messy and hidden. Moreover according to Sri Mulyani Indrawati, managing director and chief operating officer of the World Bank, if managed well urbanization could lead to sustainable growth by increasing productivity, allowing innovation and new ideas to emerge in South Asia.

At the same time UN report (2014) explained that South Asia has experienced a long period of robust economic growth and it has been among the fastest growing in the world. Growth is projected to steadily increase from 7 per cent in 2015 to 7.6 per cent by 2017 through maintaining strong consumption and increasing investment. Being the world's largest working-age population, a quarter of the world's middle-class consumers, the largest number of poor and undernourished in the world, South Asia will play an important role in the global development story as it takes its place in the Asian countries.

Figure 1. Growth (\%) statistics of South Asia

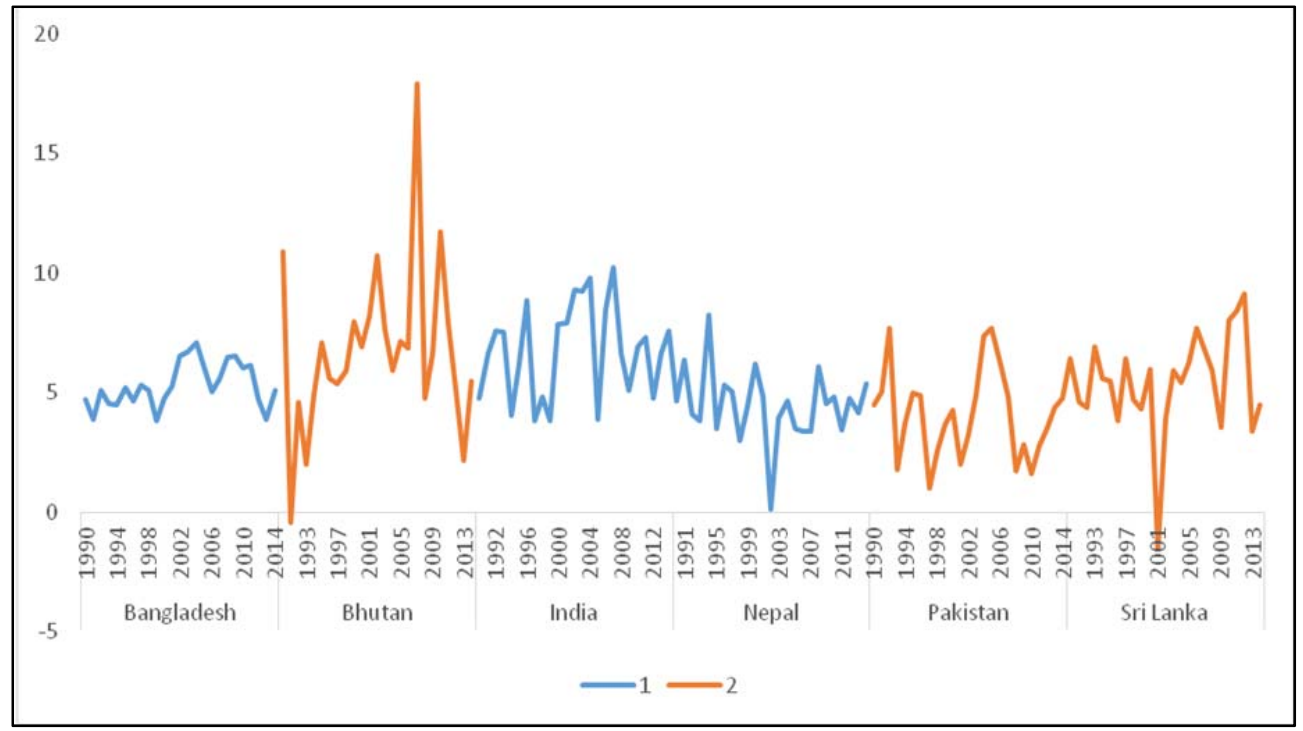

Source: World Development Indicator, 2015 (Data on Afghanistan and Maldives are unavailable) 
From Figure 1 we can see that Bangladesh has been able to maintain a steady growth of 6 per cent over the past few years. India made significant progress in the last two years followed by Pakistan as well. At the same time Nepal also made a rapid progress in the last three years.

\section{Data, Model and Strategy}

\subsection{Data}

Tables 1 and 2 provide the descriptive statistics of the variables used in this study. In this study our dependent variable is GDP (constant 2005 US\$) and independent variable is Urban population (\% of total). Here urban population refers to people living in urban areas as defined by national statistical offices. It is calculated using World Bank population estimates and urban ratios from the United Nations World Urbanization Prospects (WDI, 2015). On the other hand GDP at purchasers' prices is the sum of gross value added by all resident producers in the economy plus any product taxes and minus any subsidies not included in the value of the products. It is calculated without making deductions for depreciation of fabricated assets or for depletion and degradation of natural resources. Here the study chose GDP at constant price rather than GDP growth (\%) because we want to measure the actual changes that take place in the economy of south Asian countries. Data are in constant 2005 in United States (US) dollars (WDI, 2015). Data has been collected from world development indicators of World Bank data sheet from 1980 to 2014. We have used panel data of six South Asian countries e.g. Bangladesh, India, Sri Lanka, Nepal, Bhutan \& Pakistan. The study didn't use the panel data of other two countries e.g. Afghanistan \& Maldives because of unavailability of long term panel data. Eviews 9 has been used to analyze the data.

Table 1: Descriptive Statistics of GDP (constant 2005 in billion US\$) in South Asia

\begin{tabular}{c|ccccc}
\hline Country & Mean & Median & CV & Maximum & Minimum \\
\hline Bangladesh & 54.98 & 46.76 & 0.5 & 118.89 & 23.15 \\
India & 638.88 & 502.14 & 0.63 & 1598.32 & 203.97 \\
Sri Lanka & 19.66 & 17.36 & 0.51 & 42.49 & 8.02 \\
Pakistan & 82.75 & 77.33 & 0.42 & 150.57 & 31.71 \\
Nepal & 6.35 & 6.02 & 0.43 & 12.01 & 2.66 \\
Bhutan & 0.62 & 0.46 & 0.69 & 1.57 & 0.13 \\
\hline
\end{tabular}


Table 2: Descriptive Statistics of Urban population (\% of total) in South Asia

\begin{tabular}{c|ccccc}
\hline Country & Mean & Median & CV & Maximum & Minimum \\
\hline Bangladesh & 23.22 & 22.43 & 0.22 & 33.51 & 14.85 \\
India & 23.32 & 27.02 & 0.11 & 32.37 & 23.09 \\
Sri Lanka & 18.48 & 18.48 & 0.006 & 18.77 & 18.29 \\
Pakistan & 32.64 & 32.34 & 0.09 & 38.3 & 28.06 \\
Nepal & 11.94 & 11.85 & 0.32 & 18.24 & 6.09 \\
Bhutan & 23.18 & 22.4 & 0.38 & 37.89 & 10.13 \\
\hline
\end{tabular}

\subsection{Econometric Modeling}

To analyze the relationship between urban population and economic growth in an analytical manner the study has employed an econometric modeling which consists of panel unit root, panel co-integration and panel causality. At first we have employed panel unit root test to check the stationarity of panel data used. The power of panel unit root tests is considered to be higher compared to individual unit root tests since the information in the time series is enhanced by that contained in the cross-section data. However due to the lack of power of conventional unit root tests, panel unit root tests have been developed quickly in recent twenty years. The traditional augmented Dickey Fuller (ADF) (Dickey and Fuller, 1979) test is generally considered weak in testing stationarity for panel data since they contain both time and cross section dimensions. Studies on panel unit root tests include Hadri (2000), Im et al. (2003), Levin et al. (2002) and Maddala and $\mathrm{Wu}$ (1999). The most popular tests in recent applications are Levin et al. (2002) and Im et al. (2003). In this study we have checked the unit root of our data by all the methods stated above. If the series are individually integrated of the same order, then we can run co-integration to determine their long run relationship. Traditional co-integration tests (Johansen, 1988) have been used to identify the existence of long-run relationships between integrated variables in time series data. However as the time passes, new methods have been developed e.g. Pedroni (1999), Kao (1999). Pedroni (1999) proposed a method for panel data cointegration test that can be considered as an extension of the traditional Johansen cointegration test (Johansen, 1988). In our study we used all the tests to ensure the accuracy of results. However, the presence of a cointegration relationship cannot explain the direction of causality among the variables. In order to analyze the direction of causality, a panel-based vector error correction model (VECM) should be performed Bruno (2005). Now if there exists a cointegration then the direction of causality can be estimated by using the VECM. Through vector error correction model, we can determine their long run as well as short run relationship. In the short-run, then a panel vector error-correction model allows for the interaction of short-run dynamics across cross-sections. The two-equation VECM short run model can be written as follows:

$\Delta \mathrm{y}_{\mathrm{t}}=\mathrm{C}_{0}+\sum \beta_{i} \Delta \mathrm{y}_{\mathrm{t}-\mathrm{i}}+\sum \alpha_{i} \Delta x_{t-I}+\rho_{i} E C T_{t-i}+\mathrm{u}_{\mathrm{t}}$

$\Delta \mathrm{y}_{\mathrm{t}}=\mathrm{C}_{0}+\sum \gamma_{i} \Delta x_{t-i}+\sum \zeta_{\mathrm{I}} \Delta y_{t-i}+\eta_{\mathrm{i}} E C T_{t-i}+\varepsilon_{\mathrm{t}}$

where $\Delta$ is the difference operator; $k$, is the numbers of lags, ai and $\zeta \mid$ are parameters to be estimated, ECTt-i represents the error terms derived from the long-run cointegration relationship. In each equation, the change in the dependent variable is caused not only by the lag, but also by the previous period's disequilibrium level. 


\section{Results and Discussion}

In this study we used four methods that have been used to check the accuracy of stationarity of the panel data. It includes Levin, Lin and Chu, Im. Pesaran and Shin, Augmented Dickey Fuller Test and Phillips Prennon test. Table 3 states the unit root test results of dependent variable GDP. Here all the four results state that GDP variable becomes stationary in their level and first difference. However they become stationary in their second difference.

Table 3: Unit Root Test (GDP)

\begin{tabular}{c|ccc}
\hline \multirow{2}{*}{ Method } & Level & $1^{\text {st }}$ Difference & Second Difference \\
\cline { 2 - 4 } & Probabilities & Probabilities & Probabilities \\
Levin, Lin and Chu t* & 1.0000 & 0.7119 & 0.0000 \\
Im, Pesaran and Shin W- & 1.0000 & 0.8801 & 0.0000 \\
stat & 1.0000 & 0.3372 & 0.0000 \\
ADF - Fisher Chi-square & 1.0000 & 0.1043 & 0.0000 \\
\hline PP - Fisher Chi-square & & & \\
\hline
\end{tabular}

Similarly, our independent variable, urban population has become non-stationary at its level and first difference (Table 4). But they become stationary in its second difference. Now as all the variables are integrated of the same order, we can run co-integration to determine their long run relationship.

Table 4: Unit Root Test (Urban Population)

\begin{tabular}{c|ccc}
\hline \multirow{2}{*}{ Method } & Level & $1^{\text {st }}$ Difference & Second Difference \\
\cline { 2 - 4 } & Probabilities & Probabilities & Probabilities \\
Levin, Lin and Chu t & 0.9999 & 1.0000 & 0.0000 \\
Im, Pesaran and Shin W- \\
stat
\end{tabular}

In the co-integration tests we used all the methods to check the accuracy of the results. Table 5 shows the Pedroni Residual Cointegration test results. Here all the probability statistics suggest that there exist long run relationships between the variables. Here lag has been selected based on the AIC value. In general the rule is lower the AIC better the model. 
Table 5: Pedroni Residual Cointegration Test

\begin{tabular}{|c|c|c|c|c|}
\hline \multicolumn{5}{|c|}{ Trend assumption: Deterministic intercept and trend } \\
\hline \multicolumn{5}{|c|}{ Alternative hypothesis: common AR coefs. (within-dimension) } \\
\hline & & & Weighted & \\
\hline & Statistic & Prob. & Statistic & Prob. \\
\hline Panel v-Statistic & $-\overline{-3.201272}$ & $\overline{0.9993}$ & $-\overline{-3.000223}$ & $\overline{0.9987}$ \\
\hline Panel rho-Statistic & -7.283809 & 0.0000 & -7.765958 & 0.0000 \\
\hline Panel PP-Statistic & -47.59777 & 0.0000 & -41.87995 & 0.0000 \\
\hline Panel ADF-Statistic & -13.06838 & 0.0000 & -12.02557 & 0.0000 \\
\hline \multicolumn{5}{|c|}{ Alternative hypothesis: individual AR coefs. (between-dimension) } \\
\hline & Statistic & Prob. & & \\
\hline Group rho-Statistic & -5.572512 & 0.0000 & & \\
\hline Group PP-Statistic & -49.11905 & 0.0000 & & \\
\hline Group ADF-Statistic & -13.19536 & 0.0000 & & \\
\hline
\end{tabular}

Table 6 portrays the results of Kao Residual Cointegration Test. Results states that there is also long run relationship between the variables used in this study. Or we can interpret that all the variable move together in the long run.

Table 6: Kao Residual Cointegration Test

\begin{tabular}{c|cc}
\hline & $t$-Statistic & Prob. \\
\hline ADF & 1.699912 & 0.0446 \\
Residual variance & 1.546520 & \\
HAC variance & 9.057518 & \\
\hline
\end{tabular}

Finally table 7 shows the traditional Johansen Fisher Panel Cointegration test results. It also indicates that there is at least one co-integration between the variables. So all the results suggest that there exist cointegration between the variables used in this study.

Table 7: Johansen Fisher Panel Cointegration Test

\begin{tabular}{c|cccc}
\hline \multicolumn{4}{c|}{ Unrestricted Cointegration Rank Test (Trace and Maximum Eigenvalue) } \\
\hline Hypothesized & Fisher Stat. ${ }^{*}$ & Fisher Stat. ${ }^{*}$ \\
No. of CE(s) & (from trace test) & Prob. & (from max-eigen test) & Prob. \\
None & 126.4 & 0.0000 & 107.0 & 0.0000 \\
At most 1 & 55.98 & 0.0000 & 55.98 & 0.0000 \\
\hline
\end{tabular}

As all variables are cointegrated of the same order, we can run the VECM. Table 8 shows the long run causality model. Here C (1) is the error correction term which represents the speed of the adjustments towards long run equilibrium. C (1) is the residuals of the one period lag of the cointegrating vector between GDP growth and urban population growth. We see that our $C(1)$ is negative and is also significant which indicates that there is long run causality running from urban population growth to GDP. Further we can interpret urban population growth has influence on our dependent variable GDP in the long run. 
Table 8: Long run causality model

\begin{tabular}{c|cccc}
\hline & Coefficient & Std. Error & t-Statistic & Prob. \\
\hline C(1) & -2.437739 & 0.179264 & -13.59859 & 0.0000 \\
C(2) & 0.894293 & 0.129008 & 6.932092 & 0.0000 \\
C(3) & 0.294118 & 0.076479 & 3.845758 & 0.0002 \\
C(4) & -8.493409 & 1.035410 & -0.827385 & 0.4092 \\
C(5) & -4.151309 & 7.905609 & -0.525356 & 0.6000 \\
C(6) & 51048906 & 5.005408 & 0.102069 & 0.9188 \\
R-squared & 0.731261 & Mean dependent var & 1.185408 \\
Adjusted R-squared & 0.723538 & S.D. dependent var & 1.277756 \\
S.E. of regression & 6.709609 & Akaike info criterion & 48.12079 \\
Sum squared resid & 7.815421 & Schwarz criterion & 48.22722 \\
Log likelihood & -4324.871 & Hannan-Quinn criter. & 48.16394 \\
F-statistic & 94.69346 & Durbin-Watson stat & 1.921217 \\
Prob(F-statistic) & 0.000000 & & \\
\hline
\end{tabular}

Now we want to estimate whether there is any short run causality between the variables. To do this we used Wald statistics test results. Table 10 shows short run causality results between urban population (percentage of total) and GDP. The result suggests that there is no short run causality between urban population (percentage of total) and GDP since chi-square value is less than 5 per cent.

Table 9: Short run causality between GDP and Urban population growth

\begin{tabular}{c|ccc}
\hline Wald Test Statistic & Value & $d f$ & Probability \\
\hline F-statistic & 0.383257 & $(2,174)$ & 0.6822 \\
Chi-square & 0.766514 & 2 & 0.6816 \\
\hline
\end{tabular}

Moreover, Figure 2 shows that residuals of our model are normally distributed. Further our R2 value is 73 per cent which is high. Also our F value is found to be significant at 5 per cent level of significance. Therefore we can conclude that model used in this study is good fit.

Figure 2: Normality Test

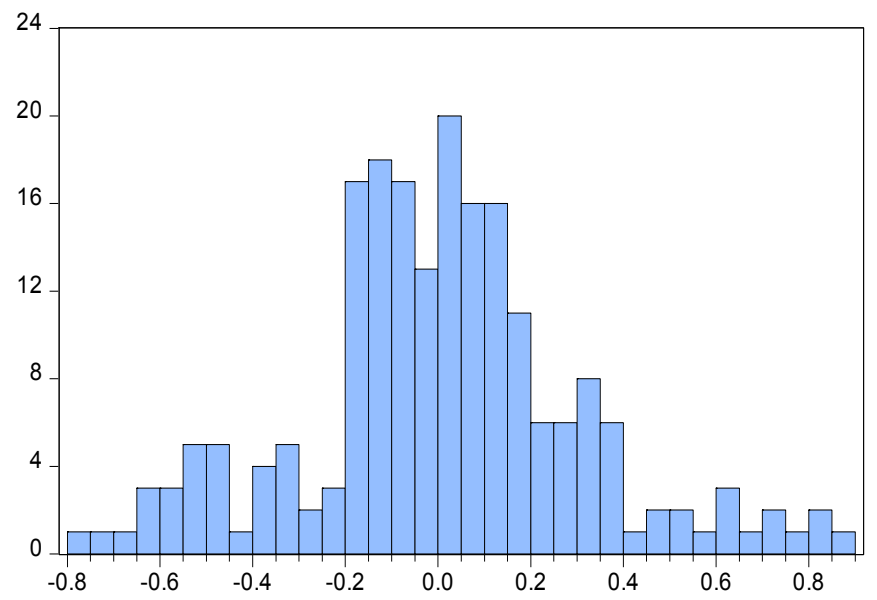

\begin{tabular}{ll}
\hline \multicolumn{2}{l}{ Series: Residuals } \\
Sample 1981 2014 \\
Observations 204 \\
Mean & 0.006262 \\
Median & 0.005419 \\
Maximum & 0.883115 \\
Minimum & -0.765186 \\
Std. Dev. & 0.302364 \\
Skewness & 0.175789 \\
Kurtosis & 3.615320 \\
& \\
Jarque-Bera & 4.268924 \\
Probability & 0.118308 \\
\hline
\end{tabular}




\section{Conclusion and policy recommendation}

So far our study has found long run causal relationship between urban population and economic growth in South Asia. However in the short run, our study found no relationship between the variables. Therefore it can be said that urban population growth does not immediately affect the economic growth in South Asia. Rather in the long run, urban population growth significantly affects the economic growth in South Asia. Our results are very much consistent with the findings of Fay and Opal (2000); and Polese (2005). In South Asia, urban population is growing at a higher rate. Therefore South Asian countries should develop aggressive programs of accelerated urbanization designed to spur economic growth. As the world continues to urbanize, sustainable development challenges will be increasingly concentrated in cities, particularly in the regions like South Asia where the speed of urbanization is one of the quickest. Governments must implement policies to ensure that the benefits of urban growth are shared equitably and sustainably. Sustainability requires cities that generate better income and employment opportunities in order to expand the necessary infrastructure for water and sanitation, energy, transportation as well as information and communications. Successful sustainable urbanization requires competent, responsive as well as accountable governments, charged with the management of cities and urban expansion. It also requires appropriate use of information and communication technologies for more efficient service delivery. Urbanization is a complex issue that must be assessed not only in terms of urbanization speed or effects of economic growth. In order to increase the quality of the urbanization process, the forward conditions and backward effects must also be explored. It is suggested that the evaluation of urbanization can be improved from the following two aspects. First, the forward conditions of urbanization can be analyzed, such as the number of non-farm jobs, infrastructure level and the supply capacity of public services. Second, the forward effects of urbanization should be comprehensively evaluated, including economic, social, and environmental sustainability. Policymakers in South Asian countries should seek multiple ways of enabling forms of urbanization that contribute to economic growth, an increase in jobs, environmental sustainability, and so on, rather than pursuing accelerated urbanization. Our study has attempted to identify the long run relationship between urban population and economic growth in South Asia using panel data analysis. We have found long run causal relationship running from urbanization to economic growth in South Asia. South Asian economies are growing at a faster rate over the last few years. Therefore the challenge is how to utilize those rising urban inhabitants to accelerate economic growth in South Asia. In the long term, successful urbanization is accompanied by the convergence of living standards between urban and rural areas as economic and social benefits spill beyond urban boundaries. Our empirical findings suggest several policy implications. South Asian countries should focus on building institutional capacities and applying integrated approaches so as to attain urban sustainability. At the same time in designing urban policies and reforms, it is essential to pay attention to the political economy of urbanization. Urban infrastructure service delivery and urban land management need to be strengthened in order to hold the economic growth in south Asia. Although progress since 2000 has been impressive, the majority of South Asia's cities remain characterized by high levels of poverty, bad housing conditions, and generally poor livability for many of their inhabitants. Therefore it is highly recommended that policymakers need to pay special attention to utilize the population portfolio of South Asia in order to accelerate the economic growth of that region. However the study has used only two variables for a panel analysis. Therefore the study recommends that future research should be conducted by adding more variables e.g. education, corruption index, governance indicator index and so on to interpret the relationship with economic growth in South Asia. 


\section{References}

Alam, Shaista, Ambreen Fatima, and Muhammad S. Butt (2007) 'Sustainable Development in Pakistan in the context of energy consumption demand and environmental degradation', Journal of Asian Economics 18(5): 825-837.

Bacolod, Marigee, Bernardo S. Blum, and William C. Strange (2010) 'Elements of skill: traits, Intelligences, Education, and Agglomeration', Journal of Regional Science 50(1): 245-280.

Becker Charles M. (2007) 'Urbanization and rural-urban migration' in Amitava Dutt, and Jaime Ros, (Eds). International Handbook of Development Economics. Cheltenham: Edward Elgar, pp. 516-532.

Bloom, David E., David Canning, and Günther Fink (2008) 'Urbanization and the wealth of nations', Science 319(5864): 772-775.

Bruno, Giovanni S. F. (2005) 'Approximating the Bias of the LSDV Estimator for Dynamic Unbalanced Panel Data Models', Economics Letters 87(3): 361-366.

Castells-Quintana, David (2011) 'Agglomeration, Inequality and Economic Growth: Cross-section and panel data analysis' Research Institute of Applied Economics Working Paper 2011/14.

Chen, Mingxing, Hua Zhang, Weidong Liu, and Wenzhong Zhang (2014) 'The Global Pattern of Urbanization and Economic Growth: Evidence from the Last Three Decades', PLOS ONE 9(8): e103799.

Dickey, David A., and Wayne A. Fuller (1979) 'Distribution of the estimators for autoregressive time series with a unit root', Journal of the American statistical association 74(366a): 427-431.

Ellis. Peter (2015) South Asia Not Taking Full Economic Advantage of Urbanization. World Bank Press Release. Access from: http://www.worldbank.org/en/news/press-release/2015/09/24/south-asia-not-takingfull-economic-advantage-urbanization Fay, Marianne, and Charlotte Opal (2000) Urbanization without Growth: a not so Uncommon Phenomenon. Washington DC: World Bank Publication.

Friedberg, Rachel M., and Jennifer Hunt (1995) 'The Impact of Immigrants on Host Country Wages, Employment and Growth (in Symposia: Immigration)', The Journal of Economic Perspectives 9(2): 23-44.

Glaeser, Edward L., Stuart S. Rosenthal, and William C. Strange (2010) 'Urban economics and entrepreneurship', Journal of Urban Economics 67 (1): 01-14.

Hadri, Kaddour (2000) 'Testing for stationarity in heterogeneous panel data', Econometrics Journal 3 (2): 148-161.

Im, Kyung So, M. Hashem Pesaran, and Yongcheol Shin (2003) 'Testing for unit roots in heterogeneous panels', Journal of Econometrics 115(1): 53-74.

Indrawati, Sri Mulyani (2015) Who sets the rules of the game in Asia? East Asia Forum. Access From http://blogs.worldbank.org/voices/who-sets-the-rules-of-thegame-in-asia

Johansen, Søren (1988) 'Statistical analysis of cointegration vectors', Journal of Economics Dynamic and Control 12(2-3): 231-254.

Kao, Chihwa (1999) 'Spurious regression and residual-based tests for cointegration in panel data', Journal of Econometrics 90(1): 01-44.

Kasman, Adnan, and Yavuz Selman Duman (2015) 'CO2 emissions, economic growth, energy consumption, trade and urbanization in new EU member and candidate countries: A panel data analysis', Economic Modelling 44(1): 97-103. 
Levin, Andrew, Chien-Fu Lin, and Chia-Shang James Chu (2002) 'Unit root tests in panel data: asymptotic and finite-sample properties', Journal of Econometrics 108(1): 01-24.

Maddala, Gangadharrao S., and Shaowen Wu (1999) 'A comparative study of unit root tests with panel data and a new simple test', Oxford Bulletin of Economics and Statistics 61 (1): 631-652.

Mills, Edwin S., Charles M. Becker, and Satyendra Verma (1986) Studies in Indian Urban Development. Oxford: Oxford Univ. Press

Pedroni, Peter (1999) 'Critical values for cointegration tests in heterogeneous panels with multiple regressors', Oxford Bulletin of Economics and Statistics Special issue.

Polèse, Mario (2005) 'Cites and National Economic Growth: A Reappraisal', Urban Studies 42(8): 1429-1451.

Quigley John M. (2007) Urbanization, Agglomeration and economic Development. Paper presented at the World Bank Seminar on Growth and Development, , Washington, D.C.

Rosenthal, Stuart S. and William C. Strange (2003) 'Geography, Industrial Organization, and Agglomeration', Review of Economics and Statistics 85(2): 377 393.

Shabu. Terwase (2010) 'The Relationship between Urbanization and Economic Development in Developing Countries', International Journal of Economic Development Research and Investment 1(2): 30-36.

The World Bank, World Development Indicators (2015). [API_NY.GDP.MKTP.KD.ZG_DS2_en_v2]. Retrieved from: http://data.worldbank.org/indicator/NY.GDP.MKTP.KD

Turok, Ivan, and Gordon McGranahan (2013) 'Urbanization and economic growth: the arguments and evidence for Africa and Asia', Environment and Urbanization 25(1), 465-482.

United Nations (2005), World Population Prospects: The 2004 Revision. CD-ROM Edition - Extended Dataset.

United Nations (2014) World Urbanization Prospects. United Nations, Department of Economic and Social Affairs. 